\title{
PERHITUNGAN POTENSI KERUGIAN SEKTOR PETERNAKAN AKIBAT ERUPSI GUNUNG AGUNG DI DESA PEMPATAN, KECAMATAN RENDANG, KARANGASEM
}

Kadek Rudiawan ${ }^{1}$, Wayan Damar Windu Kurniawan ${ }^{2}$

${ }^{12}$ Program Studi Survei dan Pemetaan (D3), Fakultas Hukum dan Ilmu Sosial,

Universitas Pendidikan Ganesha

\begin{abstract}
Pempatan village is one of the areas in Rendang District which is in the alert zone of eruption, and has a very high risk of disaster in its economic sector, especially in the livestock sector. This study aims to determine the amount of potential loss in terms of the aspect of selling livestock after the eruption of Mount Agung, in the Pempatan Village. The method used in this research is a comprehensive observation and survey method to record the number of livestock in the study area, and is carried out through an appraisal process based on the average selling price approach within a certain period of time. The results showed, Dusun (sub-village) Teges has the highest potential loss when a disaster occurs, with an estimated potential loss of nearly 3 billion rupiah per year. Meanwhile, in general, Pempatan Village has potential losses in the livestock sector of more than 5 billion rupiah / year.
\end{abstract}

Keywords; Potential Losses, Livestock Sector, Eruption

\begin{abstract}
Abstrak
Desa pempatan adalah salah satu wilayah di Kecamatan Rendang yang masuk ke dalam daftar desa yang berada di zona awas, sehingga memiliki risiko bencana yag sangat tinggi pada sektor perekonomiannya, khususnya pada sektor peternakan. Penelitian ini bertujuan untuk mengetahui besaran potensi kerugian ditinjau dari aspek penjualan ternak pasca erupsi Gunung Agung, di Desa Pempatan. Metode yang digunakan dalam penelitian ini adalah metode observasi dan survey secara menyeluruh untuk mendata jumlah ternak yang ada di wilayah kajian, yang kemudian dilakukan proses penilaian berdasarkan pendekatan harga jual rata - rata dalam kurun waktu tertentu. Hasil penelitian menunjukkan, Dusun Teges memiliki potensi kerugian tertetinggi saat terjadi bencana, dengan perkiraan potensi kerugian mencapai hampir 3 milyar rupiah per tahun. Sementara itu, secara umum Desa Pempatan memiliki potensi kerugian di sektor peternakan mencapai lebih dari 5 milyar rupiah / tahun.
\end{abstract}

Kata Kunci : Potensi Kerugian, Sektor Peternakan, Erupsi

\section{Pendahuluan}

Gunung api merupakan setiap proses alam yang berhubungan dengan kegiatan gunungapi, meliputi asal-usul pembentukan magma di dalam bumi hingga kemunculannya di permukaan bumi dalam berbagai bentuk dan kegiatannya setiap magma yang muncul ke permukaan bumi.(Bronto,2006), yang terbentuk sejak jutaan tahun lalu hingga sekarang. Pengetahuan tentang gunung api berawal dari perilaku manusia dan manusia purba yang mempunyai hubungan dekat dengan gunung api. Hal tersebut diketahui dari penemuan fosil manusia di dalam endapan vulkanik dan sebagian besar penemuan fosil itu ditemukan di Afrika dan Indonesia berupa tulang belulang manusia yang terkubur oleh endapan vulkanik, (Vulcanological Survey of Indonesia, 2007). Indonesia berada di jalur gempa teraktif didunia karena dikelilingi oleh cincin api Pasifik dan berada di atas tiga tumbukan lempeng benua, yakni indo-australia dari sebelah selatan, Eurasia dari sebelah utara, dan pasifik dari sebelah timur. Kondisi geografis seperti ini yang menyebabkan indonesia sebagai wilayah yang rawan bencana letusan gunung api, namun dalam sisi lain menjadikan indonesia sebagai wilayah yang subur dan kaya secara hayati.

Pada tahun 2012 Indonesia tercatat memiliki 127 gunung berapi yang masih aktif, salah satu bagian dari gunung berapi tersebut adalah Gunung Agung yang terletak di Kabupaten Karangasem, Provinsi Bali, yang memiliki ketinggian $3.031 \mathrm{mdpl}$. Gunung Agung tercatat sudah 5 kali erupsi yang terjadi pada tahun 1808, 1821, 1843, 1963, dan erupsi terakhir terjadi pada tahun 2017 (BNPB 2017). Dalam hal ini banyak dampak yang dihasilkan dari bencana erupsi gunung yang tidak hanya dirasakan di wilayah yang berada di zona awas saja,namun juga di luar zona awas juga mengalami dampak serupa. Hal ini disebabkan karena erupsi gunung mengeluarkan material 
piroklastik atau abu, material ini terbentuk dari letusan gunung yang membentuk tiang asap yang cukup tinggi, ada saat energinya habis, abu menyebar sesuai dengan arah angin kemudian jatuh lagi ke permukaan Bumi. Hal ini yang menjadi penyebab wilayah yang berada jauh dalam zona awas juga terdampak. Salah satu wilayah yang memiliki zona awas maupun perluasanya, namun terkena dampak dari abu erupsi Gunung Agung adalah Kecamatan Rendang.

Kecamatan Rendang adalah Kecamatan yang terletak dekat dengan lereng Gunung Agung sehingga kecamatan Rendang menjadi salah satu wilayah yang terkena dampak dari erupsi Gunung Agung. Kecamatan rendang memiliki sektor perekonomian yang sangat besar seperti sektor wisata, sektor peternakan, dan sektor perkebunan, saat terjadinya erupsi Gunung Agung sektor perekonomian di kecamatan Rendang memiliki dampak yang dapat menimbulkan kerugian sangat besar, salah satunya sektor perekonomian di Desa pempatan. Desa pempatan adalah salah satu sektor Peternakan di kecamatan rendang yang masuk ke dalam daftar desa yang berada di zona awas, sehingga memiliki risiko bencana yag sangat tinggi pada sektor perekonomiannya. Berdasarkan hal tersebut maka sektor peternakan di desa Pempatan perlu ditelah lebih dalam supaya masyarakat dan pemerintah dapat mengetahui tingkat bahaya dan besar kerugian yang dialami oleh masyarakat setempat pasca terjadinya erupsi Gunung Agung. Berdasarkan hal tersebut, penelitian ini difokuskan kepada potensi kerugian pada penjualan ternak pasca erupsi Gunung Agung, di Desa Pempatan.

\section{Metode Penelitian}

\section{Rancangan Penelitian}

Rancangan penelitian yang digunakan adalah Penelitian survei dengan metode Sensus. Penelitian survei adalah Penyelidikan yang dilakukan untuk mendapatkan fakta dari gejala yang ada dan mencari keterangan-keterangan secara faktual baik tentang institusi sosial, ekonomi atau politik dari suatu kelompok atau individu. (M.Nazir, 2005). Metode yang digunakan adalah metode sensus, yang artinya dalam penelitian ini populasi atau elemen di ambil secara keseluruhan. Metode ini digunakan karena dalam penelitian ini akan dibuat peta persebaran peternakan, sehingga semua lokasi peternakan di Desa Pempatan dapat terpetakan. Jenis penelitian ini adalah Penelitian kuantitatif, penelitian kuantitatif adalah jenis penelitian yang menggunakan proses data-data yang berupa angka sebagai alat menganalisis dan melakukan kajian penelitian, terutama mengenai apa yang sudah di teliti (Kasiram 2008). Berdasarkan pendapat tersebut maka dalam penelitian ini digunakan metode deskriptif kuantitaif, artinya adalah dalam penelitian ini akan dijelaskan mengenai deskripsi dari angka-angka yang sudah di olah secara sistematis.

Variabel dan Definisi Operasional Variabel Penelitian

Berdasarkan rumusan masalah yang di kaji maka dalam penelitian ini dapat ditentukan variabel penelitian, yaitu Potensi Bahaya, dan Potensi kerugian, hubungan antar variabel tersebut adalah potensi bahaya gunung agung yang berpengaruh terhadap potensi kerugian sektor peternakan di Desa Pempatan. Semakin tinggi potensi bahaya yang ditimbulkan maka semakin tinggi potensi kerugian yang dialami, dan juga sebaliknya. Merujuk dari variabel tersebut, potensi bahaya yang dikaji dalam penelitian ini adalah potensi bahaya yang dapat ditimbulkan dari erupsi gunung agung, seperti definisi bahaya bencana yang dijelaskan dalam kajian teori, tedapat beberapa bahaya yang dapat ditimbulkan jika terjadi erupsi gunung, seperti jatuhan piroklastik ( awan panas), aliran piroklastik, banjir bandang dan yang lainnya. Sedangkan potensi kerugian yang dikaji dalam penelitian ini adalah potensi kerugian Harga jual ternak yang dialami oleh peternak akibat dari erupsi Gunung Agung.

\section{Metode dan Instrumen Pengumpulan Data} Wawancara

Menurut P. Joko Subagyo (2011:39), Wawancara adalah Suatu kegiatan dilakukan untuk mendapatkan informasi secara langsung dengan mengungkapkan pertanyaanpertanyaan pada para responden. wawancara bermakna berhadapan langsung antara interview dengan responden, dan kegiatannya dilakukan secara lisan. Teknik Wawancara ini dilakukan untuk memperoleh informasi atau keterngan secara lengkap mengenai objek yang akan diteliti dan keterangan data lainnya yang diperlukan dalam penelitian. Hasil dari wawancara ini adalah data jumlah ternak dan batas Dusun di Desa Pempatan.

Observasi

Observasi adalah teknik pengumpulan data dengan cara melakukan survei lapangan dan pencatatan secara langsung mengenai objek penelitian. Teknik ini dilakukan untuk mengetahui 
persebaran dari lokasi peternakan di Desa Pempatan, selain itu teknik ini juga digunakan untuk mengetahui batas dusun di desa pempatan.

Dokumentasi

Teknik dokumentasi adalah pengumpulan data yang dilakukan dengan menelaah dokumendokumen yang terdapat pada suatu instansi, Lina Ismawati (2010:39). Dalam penelitian ini berdasarkan data tertulis berada di Kantor Desa Pempatan dan Kantor Badan Penanggulangan Benacana Daerah (BPBD) Kabupaten Karangasem, dan instansi lain yang terkait dengan penelitian ini.

\section{Metode dan Teknik Analisa Data}

Teknik yang digunakan dalam menganalis data penelitian ini adalah, teknik penghitungan volume dan nilai masing-masing komoditas objek yang diteliti. Dalam penghitungan ini hal yang dilakukan terlebih dahulu adalah overlay peta persebaran peternakan dengan peta KRB, sehingga nantinya didapatkan lokasi peternakan yang masuk dalam KRB. Setelah itu dilakukan analisis mengenai kerugian peternakan dengan cara penghitungan volume ternak, harga jual normal ternak dan nilai jual ternak setelah mengalami penurunan kesehatan. Setelah selesai maka akan didapatkan nilai potensi kerugian dari peternakan yang selanjutnya di sajikan dalam bentuk peta potensi kerugian peternakan setiap dusun.

\section{Hasil dan Pembahasan}

Sektor peternakan adalah sektor yang memberikan kontribusi tinggi dalam pembangunan. Sektor peternakan memiliki peluang pasar yang sangat baik, hal ini dikarekanan pasar domestik yang selalu meningkat seiring dengan pertumbuhan

Merujuk dari tabel 1, terdapat 33 titik lokasi peternakan di Desa Pempatan dengan jumlah ternak yaitu sebanyak 174.980 ekor. Harga jual ayam secara normal dan umum berdasarkan hasil wawancara dengan peternak adalah Rp.30.000. Peternak ayam akan memanen ayamnya secara normal di kisaran berat $2 \mathrm{Kg}$ dengan waktu 35 hari. Jadi untuk harga jual normal ayam dengan berat 2 Kg adalah Rp.60.000. Selanjutnya, harga jual ternak yang dilakukan secara darurat pasca terjadinya erupsi Gunung Agung berbeda dengan harga jual normal, Penjualan secara darurat ini dilakukan karena disebabkan oleh kesehatan peternakan yang menurun, menurunya kesehatan ternak ini disebabkan oleh wilayah Desa pempatan yang terdampak erupsi gunung agung, sehingga penduduk yang juga semakin pesat. Meningkatnya pendapatan penduduk akan mempengaruhi permintaan petrernakan yang juga semakin meningkat. Subsektor peternakan memiliki peranan penting dalam menopang perekonomian regional maupun nasional, masalah peternakn sudah tidak dapat dinomorduakan karena hal tersebut akan dominan ikut menentukan kelangsungan hidup suatu Negara (Saragih,2008). Hasil survei lapangan yang dilaksanakan di Desa Pempatan, sektor peternakan di desa tersebut paling banyak dibandingkan dengan desa yang lain di Kecamatan Rendang, titik lokasi peternakan tersebut tersebar di 8 dusun dari 11 dusun yang terdapat di Desa Pempatan. Berikut akan dijabarkan hasil survei lapangan persebaran titik lokasi peternakan serta jumlah titik lokasi peternakan dan jumlah ternak di setiap dusun di Desa Pempatan.

Tabel 1. Hasil Survei Titik Lokasi Peternakan

\begin{tabular}{|c|l|l|c|}
\hline No & \multicolumn{1}{|c|}{ Dusun } & $\begin{array}{l}\text { Jumlah Titik Lokasi } \\
\text { Peternakan }\end{array}$ & $\begin{array}{c}\text { Jumlah } \\
\text { Ternak }\end{array}$ \\
\hline 1 & Dusun Teges & 16 peternakan & 97.780 ekor \\
\hline 2 & $\begin{array}{l}\text { Dusun } \\
\text { Kubakal }\end{array}$ & 6 Peternakan & 15.000 ekor \\
\hline 3 & $\begin{array}{l}\text { Dusun } \\
\text { Pempatan }\end{array}$ & 6 Peternakan & 48.500 ekor \\
\hline 4 & $\begin{array}{l}\text { Dusun } \\
\text { Keladian }\end{array}$ & 1 Peternakan & 5000 ekor \\
\hline 5 & $\begin{array}{l}\text { Dusun Geliang } \\
\text { 2 Peternakan }\end{array}$ & 4000 ekor \\
\hline 6 & $\begin{array}{l}\text { Dusun Puregae } \\
1 \text { Peternakan }\end{array}$ & $\begin{array}{l}\text { 1.700 ekor } \\
\text { Pusun } \\
\text { Pemuteran }\end{array}$ & 1 Peternakan \\
\hline Jumlah & 33 Peternakan & 174.980 ekor \\
\hline
\end{tabular}

memiliki potensi bahaya seperti jatuhan piroklastik dan banjir bandang, maka peternak melakukan penjualan darurat terhadap ternak mereka untuk meminimalisir terjadinya kerugian yang lebih besar.

Berdasarkan hasil wawancara di lapangan, pasca terjadinya erupsi Gunung Agung harga jual ternak mengalami penurunan yang sangat signifikan dari harga normal yaitu dari harga normal Rp 30.000/1 $\mathrm{Kg}$, menjadi $15.000 / 1 \mathrm{Kg}$, Sehingga jika peternak melakukan penjualan darurat pada ternak yang memiliki berat $2 \mathrm{Kg}$ hanya dihargai $\mathrm{Rp} 30.000 / 2 \mathrm{~kg}$ (ukuran panen normal), harga tersebut merupakan setengah dari harga normal. Berdasarkan hal tersebut, untuk mendapatkan nilai pendapatan 
Perhitungan Potensi Kerugian Sektor Peternakan Akibat Erupsi Gunung Agung di Desa Pempatan, Kecamatan Rendang, Karangasem

norml dan kerugian pendapatan maka digunakan perhitungan sebagai berikut;
Pendapatan normal $=$ Jumlah total ternak $*$ Harga jual normal.

Kerugian pendapatan $=$ Jumlah pendapatan normal/2

Tabel 2. Hasil perhitungan jumlah pendapatan normal dan jumlah kerugian

\begin{tabular}{|c|c|c|c|c|c|}
\hline No & Dusun & $\begin{array}{c}\text { Jumlah Titik Lokasi } \\
\text { Peternakan }\end{array}$ & Jumlah Ternak & $\begin{array}{c}\text { Jumlah Pendapatan } \\
\text { Normal }\end{array}$ & Jumlah Kerugian \\
\hline 1 & Dusun Teges & 16 peternakan & 97.780 ekor & Rp 5.866.800.000 & $\operatorname{Rp} 2.933 .400 .000$ \\
\hline 2 & Dusun Kubakal & 6 Peternakan & 15.000 ekor & Rp 900.000 .000 & Rp 450.000.000 \\
\hline 3 & Dusun Pempatan & 6 Peternakan & 48.500 ekor & $\operatorname{Rp} 2.910 .000 .000$ & $\operatorname{Rp} 1.455 .000 .000$ \\
\hline 4 & Dusun Keladian & 1 Peternakan & 5000 ekor & $\operatorname{Rp} 300.000 .000$ & Rp 150.000 .000 \\
\hline 5 & Dusun Geliang & 2 Peternakan & 4000 ekor & $\mathrm{Rp} 240.000 .000$ & Rp 120.000.000 \\
\hline 6 & Dusun Puregae & 1 Peternakan & 1.700 ekor & Rp 102.000.000 & Rp 51.000.000 \\
\hline 8 & Dusun Pemuteran & 1 Peternakan & 3000 ekor & Rp 180.000.000 & $\operatorname{Rp} 90.000 .000$ \\
\hline Jun & mlah & 33 Peternakan & $174.980 \mathrm{ekor}$ & 10.498 .800 .000 & $\operatorname{Rp} 5.249 .400 .000$ \\
\hline
\end{tabular}

\section{DAFTAR PUSTAKA}

1. Rahayu P. Harkunti dan sengara Wayan I.2002. Program kesiapan sekolah terhadap bahaya gempa

2. Samuelson dan Nordhaus.1995:98. Konsep pendapatan dan` penggolongan jenis pendapatan

3. Sarwano, Jonathan. 2006. Metode Penelitian Kuantitatif \& kualitatif. Yogyakarta: Graha Ilmu
4. Vulcanological Survey of Indonesia.2007. Pembagian tingkat isyarat status Gunung Api di Indonesia.

5. Vulcanological Survey of Indonesia. 2007. Proses terbentuknya gunung api

6. Wikipedia.2017. Catatan letusan Gunung Agung, Karangasem, Bali

7. Wikipedia.2010. Erupsi Gunung Api

8. Yayasan IDEP, 2007 :22. Definisi umum tentang risiko bencana. 